\title{
HUMAN SECURITY IN EAST AFRICA: THE EAC'S ILLUSIVE QUEST FOR INCLUSIVE CITIZENSHIP
}

\author{
Barney Walsh \\ African Leadership Centre \\ King's College London, United Kingdom
}

\section{Abstract}

The East African Community (EAC) exemplifies the contradiction of independent Africa's efforts to champion regional integration and the idea of pan-Africanism, whilst maintaining the nation-state model left from colonialism. EAC I, 1967-1977, ultimately collapsed due to its inability to create a regional institutional framework that could supplant the nationalist tendencies of its member states' leaders; and failing to adopt a people-centred inclusive approach to its structure and actions. The resultant human security issues suffered throughout post-colonial East Africa at their essence have been caused by the victorious nationstate's continued failure to offer this inclusive citizenship to its peoples. Despite the EAC II's, 2001-present, espoused people-centred reincarnation, it too has so far failed to create the inclusive citizen, or peoplecentred approach to its development and so risks the continued insecurity of its people.

\section{Introduction}

We are one people ... particularly in this region, the language, the culture ... we are more or less the same. So why not? If at a certain time we were divided along certain lines at different times of history, there is nothing wrong with reconstructing what it is that we lost. So, apart from addressing the issues under the categories of defence, there are so many others ... it cannot only be defence (Ugandan 
Army Officer 2014: interview)

The 2001 incarnation of a revamped East African Community (EAC) the regional body comprised of Uganda, Tanzania and Kenya, expanded to include Rwanda and Burundi in 2007 — was a 'Mark II' version of the failed post-independence effort of the 1960s and 1970s, an institution built upon the post-colonial aspirations of creating a federated entity re-kindling the linkages which imperial powers had divided and ruled over. EAC II, with its heralded ambition of eventual political federation marking it apart from other integration efforts on the continent, was created amidst an international environment keen to champion the post-Cold War notion of human security. By definition a dynamic concept, human security is unquestionably seen as "protecting and empowering people, at the individual and community levels" and "essential to national and international security" (UN OSAA 2005: 2). Outlined clearly in the original 1994 Human Development Report, "to address the growing challenge of human security, a new development paradigm is needed that puts people at the centre of development" (UNDP 1994: 4). In essence, creating valued human security fundamentally requires economic development objectives, which is mindful of - and indeed led by - the people and communities it is aiming to make secure.

But what has been at the core of the development and security issues faced by the people of East Africa? And is the revived EAC a people-centred and human security conscious institution that has helped alleviate some of those issues? Based on secondary sources and field research interviews with EAC experts and officials, this article offers an explanation of why thus far, the EAC has failed to create a people-centred approach to tackling the fundamental insecurities faced by the people of East Africa, but nonetheless at least provides an institutional framework offering an opportunity for improvements to occur.

Following this introduction, the article provides a brief history of the first incarnation of the EAC's inability to create a regional organisation resistant to the nationalist tendencies of its member states' leaders, and failure to adopt a people-centred inclusive approach to its objectives. A section then follows incorporating analysis from Chikwanha and Oloo, showing that the subsequent human security issues suffered throughout East Africa at their essence have been caused by the continued failure of post-colonial national governments to create an inclus- 
ive sense of citizenship for all its member peoples. The fourth section indicates how EAC II apparently sought to increase regional stability by creating a more people-centred institutional framework for integration. Section five indicates how the failure to successfully achieve these goals has created a continued divide between the leaders of East Africa, between EAC II and the people; and between a human security consciousness and security cooperation in the region. Section six provides concluding remarks.

\section{EAC I - leader-centric failure}

In 1948 the British colonial administration created the East African High Commission (EAHC) and the East African Central Legislative Assembly, to control economic and political affairs, and provide a legal institutional framework to the integration efforts already underway between Kenya, Uganda and Tanganyika (which included a customs union, common currency, and the Mombasa-Kampala railway line), (Kimbugwe et al 2012: 61-63). These efforts were of course undertaken to benefit colonial interests, intending to increase markets for British companies or reduce costs of production for settlers, always with an extractive and exploitative agenda (Nabudere 2006: 3).

The first the EAC was an institutional descendent of this colonial legacy, yet also a beacon of pan-African spirit seeking to break that imperial division and subjugation. EAC I embodied the two 'conflicting dispositions' occurring in post-colonial Africa, namely a firm belief in economic integration being championed alongside the decision to maintain the colonial borders of countries (Mistry 2000: 553). Famously, Julius Nyerere stated in 1960 that his Tanganyika was willing to delay independence in order to create a united post-colonial East African Federation with Kenya and Uganda (Irele and Jeyifo 2010: 177). That dream was never realised, however, as after all three's independence in 1963, divergent development policies and political agendas of leaders became more evident — including Nyerere's increasing pre-occupation with Southern African liberation movements. Although cooperation and progress occurred within the East African Common Services Organisation which had replaced EAHC, divergence, preference for nationalism and conflictual issues were already emerging even before the 1967 signing of the EAC I treaty.

Numerous explanations have been offered as to why EAC I even- 
tually collapsed in 1977, all of which were important: the inherited colonial legacy of a more industrialised Kenya, who then continued to accrue more benefits than Tanzania ${ }^{1)}$ and Uganda without appropriate compensation mechanisms; the economic divergence of a capitalist (Kenya), African socialist (Tanzania), and mixed economy (Uganda) attempting to integrate; the personal animosity between Nyerere and Idi Amin following Amin's 1971 coup in Uganda, along with Tanzanian and Kenyan strains due to ideological differences; lack of private sector and civil society involvement; and lack of financial support for, and meaningful enforcement powers from, the EAC institution (Kimbugwe et al 2012: 64-70; Deya 2007).

Fundamentally, however, the collapse was due to the regional institution's inability to supplant the legal and governance structures of the member states. In 1963, the leaders had declared thus: "we pledge ourselves to the political Federation of East Africa ... we are nationalists and reject tribalism, racialism, or inward looking policies" (quoted in Nabudere 2006: 5). Yet the EAC I of 1967-1977 kept the 'Authority' comprising the three Presidents as the executive and highest decision making power. This meant the emerging national differences were able to disrupt and implant themselves onto the regional body, rather than the regional body being able to enforce itself on the Presidents and member states. The inherent contradiction between pan-Africanism and nationalism saw nationalism victorious. Reinforced by a Cold War era preference for nation-states (Akech 2007: 85), East Africa was unable to create an alternative vision of a genuine political federation encompassing the peoples of East Africa.

In the same way African leaders became entangled in the national problems inherited from colonialism, the EAC l's direct institutional link to the extractive and exploitative colonial federal structures also meant:

It was never intended to be of the people, for the people, serving the people, let alone incorporating the people. Issues such as human dignity, equality, equity, fairness - especially in allocation of resources and enjoyment of benefits - never formed part of its ethos. This is not to say that no individuals espoused any of these attributes. Rather, it was never a completely shared, institutional goal, visibly practised in the day-to-day operations of the organization (Deya 2007: 125). 
EAC I collapsed because it was unable to resist the forces of nationalism that exposed fundamental and serious divergence between member state leaders, but had also never been a serious people-centred institutional arrangement from its inception.

\section{Human security in East Africa}

\subsection{Role of citizenship}

The victory of nationalism and failure of a viable regional alternative saw East African leaders concentrate on their domestic development objectives - where those 'development objectives' included personal wealth extraction. This had far reaching ramifications for the peoples of East Africa, whose post-independence and post-EAC I history up to the 2000s witnessed perennial poverty, environmental degradation, hunger and disease afflicting varied and specific groups; alongside genocide and civil, inter-state and continental warfare. If a broad definition of human security can be "freedom from want and freedom from fear", (UN OSAA 2005: 4), this array of conflicts saw East Africa as exceedingly insecure.

The security issues faced can consistently be extrapolated back to the contest between citizen and nation. Belonging to a state/nation, or citizenship:

Infers that people are not only concerned with gaining the political right to vote, but also want to be involved in the social sphere and given the opportunity to take part in it so they can enjoy economic rights, human rights, and a chance to participate freely in the decision making structures (Chikwanha 2012: 15, referring to Taylor 1997).

This contestation to gain citizenship is an entirely natural phenomenon in an environment where "... countries are very new states, they were created yesterday. You do not have a very strong history of people having a sense of nationhood and togetherness" (Mwenda 2014: interview). The maintenance of the European nation-state and failure to reframe East Africa into more meaningful and engaged community groupings, created an environment with constant tension between local and national constructs. The conflictual environment was created as successive East African governments failed to create an inclusive sense of citizenship during the transition from colonialism to independence, and again in the transition from more authoritarian regimes to constitu- 
tional democracies in the 1990s (Chikwanha 2012: 16). This encouraged ethnic identities instead to be a primary source of inclusion.

As articulated by Oloo, ethnicity has been "the major contention over citizenship in East Africa" (Oloo 2007: 23). Ethnonationalism has been an effective counter-ideology to the state-centric nationalism, with ethnicity's emotive character making it a strong mobilising force and helping to create a hierarchy amongst groups in terms of "political and socioeconomic advancement, and access to, and actual control of political power and the public sector" (Oloo 2007: 23). The nation-state's failure to address ethnic issues, and often perpetuate them, saw the politicisation of ethnicity most evident in Kenya, Rwanda and Burundi, which has created gross insecurity with the denial of citizenship rights to certain groups; but also a Uganda which has the 'Buganda' question remaining core to its development, and a Tanzania unreconciled between the mainland and Zanzibar island (Chikwanha 2012: 20-21; Oloo 2007).

\subsection{Patterns of conflict}

Whether consciously or sub-consciously realised by the actors involved, the prominent sources of conflicts in East Africa can be drawn back to this fundamental negotiation, or conversation, between citizen and state. Different groups and communities share stories and show histories of battling with central government for recognition of their rights or access to resources deprived to them. Although differences occur between the narratives and underlying grievances that shape them, "the experiences of political, social and economic marginalisation essentially do not, thus providing fertile ground for the spread of conflict" (Boas and Jennings 2008: 168).

Inequitable distribution of resources, including water, has fuelled numerous group-to-group and group-to-state conflicts as communities and potential citizens fight for access to national wealth. The cattle rustling that has been rife in Karamoja and elsewhere sees a traditional mode of life struggling for recognition amidst the neglect of pastoralists and uneven distribution of grazing land by central government. Conflict and porous borders have helped produce a huge number of refugees in each country. As of March 2014, there were combined 1215595 refugees in the five EAC partner states, and 418284 total internally displaced persons (IDPs) in Burundi, Kenya, and Uganda (UN OCHA 
2014), resulting in security issues for the peoples and region, as refugees and IDPs struggle to negotiate successful admittance to the nation (Chikwanha 2012: 22-27). Terrorism, and the latest Al-Shabaab menace, sees people attacking directly and openly their member governments and fellow citizens, challenging their very right to structure their identity into a prescribed national formula. Relating to, and exacerbating, all of the above, Small Arms and Light Weapons (SALW) proliferation is a notoriously difficult area to tackle and quantify, but fundamentally sees excluded citizens acquiring the means to gain the resources or security their governments have restricted or been unable to guarantee them.

\subsection{An East African identity}

The pan-African agenda in East Africa was ultimately defeated by the protection and continuation of its nation-states. These subsequently failed to create true citizens able to identify with their nation. Lessons from the collapse of EAC I show that any effort by a regional institution to create an alternative inclusivist sense of citizenship must allow the people, or citizens, to be part of the negotiations and processes around its inception. That an 'East African' people and identity exists is not doubted by experts and locals. According to Justice Kanyeihamba, retired Ugandan Supreme Court Judge, "one thing I can state without any doubt, is that East Africans, rather than East African governments, are completely committed to the integration of the region, that is the greatest hope ... that thing runs through East Africa, among the people, which is a wonderful thing to have" (2014: interview). Analysts remain mostly positive about the prospects of an eventual political federation, even if the complexity of such matters inevitably makes it a prolonged process. A Kenyan economist notes that "unlike other places where the idea of political federation has generated a lot of resistance you don't actually find that resistance ... it would be a challenge if there was political resistance from the citizenry for instance, but there isn't" (Ndii 2015: interview).

Likewise economically, any regional organisation would in fact be playing catch up with the people of which it is comprised. Communities within the region, especially those living close to partner states borders, "continue to trade usually, and this trade is not guided by anyone. For them they are already in their own informal protocols" (Kabahandra 
2014: interview). As noted by Deya, however, for a successful regional institution to evolve the people "must want it, own it, design it, drive it, monitor and evaluate it, and redesign or reform it" (2007: 127). This would create an EAC that does not necessarily impose its own brand of citizenship that may exclude those who do not conform to its leaders' perceived ideal, but allows a negotiated people-centred dialogue between people and communities with national and regional structures, in order to foster the creation of an overarching sense of what constitutes East Africa and East Africans.

\section{EAC II - the people-centred revival?}

\subsection{Africa's regionalism}

In the 1990s regionalism enjoyed a resurgence as a theoretical framework for analysing post-Cold War international relations, as a method of tackling increasingly complex global security issues, and as a means of fostering supranational economic and political cooperation (El-Affendi 2009: 1-3). In Africa, this regionalism culminated with the transformation of the Organisation of African Unity (OAU) into the African Union (AU) and the development of the African Peace and Security Architecture (APSA) in the early 2000s. But this was born out of the regional organisations developing independently across the continent. Whatever the new theories or international era was contributing to this trend, this African regionalism was clearly tied to the old post-independence aspirations of enhancing continental cooperation as a means to foster economic growth and development (UN 2009: 1). As far back as 1980 the Lagos Plan of Action had advocated regional economic groupings to be strengthened and established as a stepping stone towards a united African Economic Community (OAU 1980).

The lingering pan-Africanism of the anti-colonial struggle, with its inherent tension between nationalism and regionalism, retained a direct link to the rejuvenation efforts in East Africa. Even the 1984 Mediation Agreement, which shared out the assets and liabilities of the collapsed EAC I, stated in article 14(2) that the three countries would continue to identify areas for cooperation and seek agreements to that effect. A Commonwealth Heads of State Summit in October 1991 saw rapprochement among the Presidents Moi (Kenya), Mwinyi (Tanzania) and Museveni (Uganda), leading to a decade of steady steps resulting in 
the birth of EAC II: a committee of Foreign Affairs Ministers was set up November 1991 to explore opportunities and methods for cooperation; a Permanent Tripartite Commission for East African Cooperation was then established in November 1993 with a Permanent Secretariat for the Commission launched in November 1996; April 1997 saw the first East African Co-operation Development Strategy (1997-2000) produced; and the Treaty for the Establishment of the East African Community was signed in November 1999, entered into force on 7 July 2000, and held its first Summit on 15 January 2001 (EAC).

\subsection{EAC's institutions}

The 1990s and 2000s had seen an increasing number of civil society groups operating across the East African region. While mostly remaining reliant on donor funding, often having a narrow national focus of interest, and being generally cautious about clashing full-on with government, they were nonetheless part of the social and political landscape to a far greater extent than during the EAC I era (GingyeraPinycwa 2007: 161-162). Having seen the failure of EAC I, the EAC II was to be a different entity. According to one interviewee, "when it arrived, they said it is now people centred, the previous one had just been the Presidents meeting, this one they said would be people centred" (Oguttu 2014: interview). Shem Baguime, Ugandan Minster for EAC, says partner states were intensely aware that the leadershipcentred structure of EAC I had helped lead to its collapse, and that with EAC II "we created frameworks and we were very careful and clear that the community should be people centred, and private sector driven not leadership centred ... it's the communities and people that we want to drive it" (2014: interview).

Relations between partner states were defined by mutual trust, political (good) will and sovereign equality; peaceful coexistence and good neighbourliness; peaceful settlement of disputes; equitable distribution of benefits; cooperation for mutual benefits. The trending idea of 'good governance' was also clearly and consistently defined, with the fundamental principles to be followed by partner states being "democracy, the rule of law, accountability, transparency, social justice, equal opportunities, gender equality, as well as the recognition, promotion and protection of human rights" (EAC 1999: Art 6).

The organs of EAC II are "the Summit; the Council; the Co- 
ordination Committees; Sectoral Committee; the East African Court of Justice; the East African Legislative Assembly (EALA); the Secretariat; and such other organs as may be established" (Art 9; for discussion of these and above Articles also see Gingyera-Pinycwa 2007: 163). Baguime explains that the Treaty deliberately aimed to make the Council of Ministers "the driving force of the Community", as a means of protecting against the whims of particular leaders (2014: interview). Indeed, the Summit, comprising the partner states Presidents, "shall give general directions and impetus as to the development and achievement of the objectives of the Community" (Art 11(1)). However, the Council, comprising appropriate Ministers of each country, "shall be the policy organ of the Community; initiate and submit Bills to the Assembly; and make regulations, issue directives, take decisions, make recommendations and give opinions in accordance with the provisions of this Treaty" (Art 14).

The ordering of integration was also laid out - a common market and customs union would lead to a monetary union and eventually a political union; the federation was to be the culmination rather than starting point of the arrangement (Art 5). And the principle of 'variable geometry' was also inculcated to allow for the integration process to be followed at different speeds between the countries (Art 7(e)). The wording of the treaty was kept relatively vague, the idea being that precise details and actual progression would be initiated through by subsequent negotiations and resultant protocols emanating from the institution (Nabudere 2006: 11-12).

\subsection{Lingering problems}

The treaty shows a clear conflation between 'the people' and civil society, and the private sector and markets. Whereas EAC I had emphasised common ownership of common services, the new initiative would be a child of its neo-liberal times. In its first Development Strategy, the EAC partners accepted that the current world economy meant "market mechanisms and the private sector are playing a leading role in the development process", and the Structural Adjustment Programmes underway were explicitly referred to as benefitting efforts at reversing financial crisis and encouraging economic development, with a future EAC II seen as complementing that process (EA Co-op 1997: 11).

In the EAC treaty itself, an operating principle to achieve the 
organisation's objectives include "people-centred and market-driven cooperation", indicative of their perceived inter-changeable nature (EAC 1999: Art 7(1a)). The article dealing with the "Creation of an Enabling Environment for the Private Sector and the Civil Society" includes many more references to business interests, investments and functional markets - including two subsequent Articles on strengthening the private sector, and cooperation among business organisations and professional bodies - with only one specific point on rather vaguely agreeing to "promote enabling environment for the participation of civil society in the development activities within the Community" (EAC 1999: Art 127(3); see Art 127, 129, 129).

The EAC treaty also retained key values such as sovereignty, equality and national interests, therefore keeping traditional values associated with protection of the nation-state (Gingyera-Pinycwa 2007: 162). And although apparently not 'the driving force', the position of the Summit retains prominence and ultimate authority, reviewing and initiating Council decisions and discussions, with the Council having to "implement the decisions and directives of the Summit as may be addressed to it" (Art 14(k)). More importantly, "the Summit shall initiate the process towards the establishment of a Political Federation of the Partner States by directing the Council to undertake the process" (Art 123(6)). A representative of the East African Legislative Assembly (EALA) confirms the top-down nature of the body:

The highest decision making level is the Summit which is made up of heads of state. In terms of implementation, their directives are followed up by the Council of Ministers, forwarded to the Secretariat for purposes of harmonisation, and then the EALA is supposed to make laws where necessary to give legal effect to the decisions of the Summit, (2014: interview)

Although the new treaty creates a structure where the Council of Ministers wield significantly more executive power than was allowed for under EAC I and is able to initiate discussion and action in the event of a more inactive Summit (Deya 2007: 130), in practical terms it is clear that the Minsters in the Council will be heavily influenced by their respective Presidents. The role of the Summit therefore ensures that the ultimate decision making authority of the body remains the negotiations and deliberations taking place between Presidents. 


\subsection{The importance of security}

The Human Security agenda also appeared during this time of increased global interest in regional organisations, which appreciated that the underlying cause of the violent intra-state conflict beginning to afflict Africa, "cannot be blamed only on political exclusion but also deep-seated social exclusion, relative deprivation and its attendant communal disintegration" (UN OSAA 2005: 9). In addition, in certain countries "civil strife erupted because controlling political power meant deliberately excluding the 'other' from socio-economic opportunity" (UN OSAA 2005: 9). Such an interpretation is entirely in line with the above analysis of citizenship, or lack thereof, being the key factor in creating insecurity within the East African nation-states that existed beyond EAC I.

The security element of the new African regional organisations has always been crucial and central to their development. They are the overtly crucial component to the successful functioning of the AU's African Peace and Security Architecture (APSA), having been enshrined in the AU constitution (AU, Art 3(I)). Regional Organisations also compliment the 'African Solutions to African Problems' discourse which re-emerged post-2000 (Coleman 2011). Despite a perception of EAC as an economic community that was not explicitly founded under a security mandate, security and defence was not only a key component to the revival of the federation but a driving force. According to a security expert now working at EAC it was understood that "if confidence can be built amongst the defence forces, then the rest are much easier to deal with ... Defence was the first sector to get into the cooperative sphere" (2015: interview).

The Permanent Tripartite Commission established in 1993 identified security as one of the focus points for cooperation (along with economic, immigration, political, legal and judicial affairs) (EA Co-op 1997: 3-4). At its fourth meeting it created the Inter-state Security SubCommittee (which at its first meeting immediately decided to rename itself the Inter-state Defence and Security Sub-Committee), to further coordinate the cooperation arrangements that were already taking place. ${ }^{2)}$ In 1998 - between the authoring of the First Development Strategy and the signing of EAC treaty - along with a Tripartite Agreement on Road Transport and Inland Waterway Transport Agreement, a Memorandum of Understanding (MoU) on Co-operation in Defence was signed in Arusha (EAC). The Treaty explicitly states cooperation in 
these matters is a pre-requisite for social and economic development to occur, as well as a pre-condition for eventual political federation (Art $123,124,125)$.

The Defence and Security sectors have continued to play a key part in EAC integration, with cooperation on training programmes, sharing of intelligence, joint military exercises, and sports and cultural days, eventually cemented in the 2013 Protocol on Peace and Security, and Protocol on Co-operation in Defence Affairs. The inclusion of the Security and Defence component is in fact one of the stand out features of EAC II as compared to EAC I, which made no effort or provision around cooperation in these spheres (Mohiddin 2005: 11). A Ugandan army officer explains "I can say that the East African military has actually played the vanguard role, and we believe that it is the institution that can push this" (2014: interview). A Tanzanian representative to EALA confirms, "I don't think there is any entity in the community that is more integrated than our militaries, it is incredible", and that cooperation on the ground even surpasses what is contained in official agreements (Mwinyi 2015: interview). The Protocols are therefore seen as a natural process of integration, which organically grew from the ad hoc cooperative arrangements between militaries in to a more permanent institutionalised agreement. EAC II is seen as a force for creating a secure region, and amidst discussions around admittance of Burundi and Rwanda a justification invoked for their inclusion was that it would help stabilise and bring peace to their countries, (EAC Officials 2015: interviews).

Yet that expansion brought in two more countries posing a violent threat to large numbers of their citizens, either directly or indirectly (Chikwanha 2007: 2), joining a Uganda witnessing the entrenchment of Museveni's personal rule, a Kenya locked in a constitutional crisis and about to undergo serious electoral violence, and a Tanzania with simmering animosity between the mainland and Island of Zanzibar (Nabudere 2006: 18-19). The proposed and likely expansion of including South Sudan in the EAC would again add a state struggling with citizenship conflicts between peoples and government, with resultant intense insecurity, (EAC, 24/05/15; Copnall 2014).

East African Security and Defence cooperation, therefore, began with this conceptualisation of security and defence fundamentally being intended for maintenance of state security, in fact meaning regime security. Such a regime oriented approach to security clearly challenges to issues of citizenship (Chikwanha 2007: 3), with the EAC structure not 
allowing for regional power to override those national regimes that do not necessarily or automatically adopt an inclusive and national identity orientated concept of human security.

\section{Reality over rhetoric - the continued divide}

The results of this institutional and actualised arrangement is that three potential cleavages now exist in EAC II, which if not sufficiently understood, addressed, and transformed ultimately risk a continued failure to create an inclusive sense of citizenship that has caused so much insecurity. These fundamental divides are found between and amongst the political leaders; between the EAC and peoples of East Africa; and between the security services and understanding of human security, all of which have contemporary manifestations which act as warning shots to the community.

\subsection{Divide amongst leaders}

While undoubted economic benefits have accrued across all partner states as a direct result of the institution, ${ }^{3)}$ the continued high level of poverty and lack of overall development mean that minimal resources are available to be spread evenly across the region, making pursuit of national interest a continued objective of leaders. The structure of EAC II, with the Summit of President's and EAC's inability to compel its members to act, mean vested interests and differences between leaders, ideologies, economies and nations can cause schisms and friction. According to an East African Security and Intelligence expert, "the whole thing is about egos, its about personality, its about playing regional hegemony, political economy or sometimes military, among these leaders". Museveni sees himself as the region's elder statesman, Rwanda as the young rigorous leader, Kenya the most dominant economically, and Tanzania having the deepest history and stability (2014: interview).

There is an inherent divide within EAC around the pace at which integration should proceed. In 2004 President Museveni - always the most outspoken statesmen in championing political unity — pushed his counterparts to accept the idea to 'Fast Track' the proposed steps of common market, customs union, monetary union and political union, 
with federation at that time envisaged to take place in 2010 and election for EAC President in 2013. This fast track endeavour was a somewhat bastardised version of Nyerere's original vision of political unity being the starting point rather than end goal. But according to Nabudere (who advised the committee investigating options around pace and order of integration), to think such complexities could be fast tracked between partner states effectively without requiring a long period of deep concerted programmes "was to engage in a lot of wishful thinking" (Nabudere 2006: 13-14). Another expert from that fast track committee agrees, saying of the proposed Monetary Union, "you need to have a political authority at the regional level, overseeing things or it won't work" (2014: interview).

The scars of EAC I have had their repercussions. Tanzania having arguably been the spiritual and ideological homeland of the federation through Nyerere, suffered significantly from its collapse and gained solace and benefit through its role in the Front Line States by joining the Southern African Development Coordination Conference (SADCC) which in 1992 became Southern African Development Community (SADC) (Ndulu and Mutalemwa 2002: 204). Towards EAC II integration, Tanzania sees itself as justifiably cautious. Landlocked Uganda, Rwanda and Burundi have obvious benefits of integration, and Kenya's wealth also makes it a significant business opportunity, whereas Tanzania does not have those same compelling reasons (Mwinyi 2014: interview). Tanzania's split history and divided loyalty is undoubtedly problematic. Conversations around them leaving SADC have occurred, but "because Tanzanians have suffered there, they have lost blood, they have lost resources, to ensure that those countries are liberated. So when you tell them pull out of SADC because you are in here, they don't understand" (EAC Clerk 2015: interview).

These inherent divisions can cause schisms. After the predicted delays around fast-tracked integration bore out, in 2011 an East African Team working with the EAC secretariat presented to members the draft model of what a political federation might look like. It was Tanzania who were most weary of the proposals which then encouraged Kenya, Uganda, and Rwanda to proceed with numerous integration projects without including Tanzania and Burundi, creating the so-called Coalition of the Willing (CoW) (EAC Expert advisor 2014: interview). Despite protestations from EAC officials that CoW - which they prefer to call the Northern Corridor Initiative - is an anticipated option allowed for by 
the principle of variable geometry, it is indicative of the powerful role persons and personalities clearly still have over EAC II. Rwanda's Kagame, Kenya's Uhuru, and Uganda's Museveni have a very good personal relationship which has helped spawn the CoW, "It is not based on national interest; it is based on the fact that the three of them can get along very well, yes. If Museveni and Kagame were not re-elected in 2011 we would still be at square one" (Mwenda 2014: interview).

If such personal and ideological divisions or convergence continue to play a role in EAC integration efforts, as per EAC I there is a danger that Presidential authority and leader roles domestically and regionally mean that the focus of, and forces initiating, integration remain at the elite level.

\subsection{Divide between EAC and 'the people'}

Despite the rhetoric around being a people-led and people-centred revival for EAC II, the limits of the institutional inclusion of civil society outlined above make the power of the role played by 'the people' highly questionable. EALA members are still chosen through indirect election as per EAC I, chosen by National Legislatures not the popular vote. The additional provision that all political opinion should be represented in parliament is vague and clearly not binding (Art 50). In Uganda, for example, since 2012 the opposition FDC party have boycotted EALA after domestic bickering with the ruling NRM about sharing of EALA seats amongst political parties (Daily Monitor 25/05/12).

A "programme of wide sensitisation and mobilisation" of the peoples of East Africa around the achievements, benefits and process of political federation as part of the Fast-Track endeavour proposed in 2004, has never really occurred (Nabudere 2006: 15). And the mingling of private sector with civil society sees financial institutions having more influence amidst regional integration. Regarding the Monetary Union, for example, regular meetings with the EAC Monetary Affairs Committee which links the central banks is what drives ideas and produces frameworks. This is an integral part of EAC process, without which "things like the protocol on Monetary Union wouldn't happen, there would be nothing formal for the politicians to sign up to" (Brownbridge 2014: interview).

Various significant sub-state groupings fail to feel integrated into the EAC II institution, still battling for citizenship with their nation-state, 
the EAC being one step further removed from their own identity formation. In Uganda, for example, the Buganda Kingdom has historically been an opponent of EAC federation since colonial times and retained its scepticism around EAC integration, but from the current reality rather than idea of integration:

We don't have any space or a platform to participate in this discussion when it comes to integration. So we have things dear to us that as it integrates how are we going to fit in? I think that's the challenge and the fear of the unknown, rather than being resistant per se ... we would like an input, and also share in the knowledge of what are the plans (Buganda Kingdom Minister 2014: interview).

Buganda publicly advises EALA to go slow on integration until its own status and that of Zanzibar in Tanzania has been resolved. Yet there is no dialogue and active cooperation between the Ugandan Kingdom and Tanzanian Island, working together in both pressuring their domestic governments alongside lobbying EAC for greater involvement, (URN, 05/12/14; Buganda Kingdom Minister 2014: interview). A former EALA representative explains "we don't even have a critical mass of actors across the different interest groups in the region" capable of acting domestically but coordinating regionally in order to push the integration agenda. He believes "the moment that happens then whatever they feel, the leaders will find it very difficult to impede the process" (2014: interview).

As oil and gas finds sweep across the region and impact significantly on the development agenda of EAC countries in the coming decades, the uncanny frequency with which these mineral resources are being found in historically marginalised communities makes the citizen-state-region dynamic all the more complex, as "in fact people from those areas think that is God's answer to neglect by previous administrations" (Zein 2015: interview). The long term conflict issues between groups in Turkana and West Polkot, Kenya, for example, which EAC's conflict early warning team was making efforts to improve become significantly more complicated according to the experts working in the region now that oil has been found.

There is a clear and ever present danger of reaction from those groups if they perceive further and continued dispossession, "if it is secretive, it will become a problem ... if people don't think they are getting the benefits that they think they should have, there will be prob- 
lems" (EAC Conflict Early Warning specialist 2015: interview). EALA representatives visited mining sites in Tanzania and oil sites in Uganda, and made recommendations on improved laws around transparency and equitable distribution of resources. ${ }^{4}$ Thus far, however, governments have tended to label the mega projects required for utilising such resources as state secrets. This is encouraging efforts from the EALA to legislate a freedom of information bill, "as you can't say we will not submit, the executives must submit to parliamentary scrutiny" (Zein 2015: interview).

EAC II's continued inability thus far to create a genuine peoplecentred institution and alternative sense of citizenship to that offered by partner states, risks prolonging insecurities faced by the East African populace, especially if recent and on-going oil, gas and mineral finds are not handled effectively.

\subsection{Divide from 'human security'}

The maintenance of state-hood being respected and continued prominence of the President's Summit combines with the fact that East Africa clearly maintained "a militarized concept of security which is challenged by the holistic concept of human security" (Chikwanha 2007: 3). In an environment where the stability of nation-states and ruling regimes remains highly questionable, despite the security and defence cooperation cited above, the EAC has never faced a clearly defined external enemy that can only be confronted and repelled collectively, and which obviously threatens the existence of partner states without a cooperative approach. Pursuit of individual national interests has therefore been the key driver of security concerns for ruling parties.

Terrorism is perhaps now emerging as that unifying danger and has certainly helped compel EAC cooperation, yet the varying threat levels faced by partner states by different groups clearly varies dramatically, unlike for example, the threat the Soviet Union posed to Western Europe, which helped spur the integration in Europe (Akech 2007). Inter-state rivalry therefore still remains palpable. On condition of anonymity, security specialists see Museveni and Uganda's military buildup as unnecessary and somewhat troubling, for example. Doubting the seriousness of espoused threats like Lord's Resistance Army (LRA) and Allied Democratic Forces, "I would say that any strategic thinker would say this is something that is worrisome to the region", although 
such matters and concerns are not discussed officially at the EAC (2014: interview). When effort has been made to discuss such threats - a May 2003 EALA motion tabled by Wandera Ogallo of Uganda saw a resolution passed seeking to establish a committee in order to negotiate the end of the LRA conflict in Northern Uganda - progress was not made. Despite his pan-African, regional security rhetoric, Museveni's obvious dislike for outside interference in his internal security problems meant the EALA proposal bore no fruits (EALA Hansard 21/05/03; Kayunga 2005: 216-7).

Caution in integration generally is somewhat mirrored in defence and security spheres. Tanzanian representative Mwinyi admits Tanzania consciously watered down the EAC Defence Protocol, due to its membership of SADC and draft version's confusion between police and military matters, with Tanzania accepting military cooperation to a greater extent than police affairs which should be primarily an internal matter (Mwinyi 2014: interview). The CoW divide was also exacerbated in 2013 by a very public spat between Kagame and Kikwete around Tanzania's involvement in the United Nations (UN) operation in Eastern Democratic Republic of Congo (DRC), where Rwanda has historically been very active. Kikwete's appeal for Rwanda to negotiate with Kigali's Forces démocratiques de libération du Rwanda (FDLR) nemesis caused serious issues, with Kagame publicly threatening to punch Kikwete (The Rising Continent, 04/07/13; Africa America Network, 03/07/13). Museveni apparently had to intervene "and Kagame backed off, but there is still visible evidence of unresolved issues between the two" (East African Security and Intelligence expert 2014: interview). From the Tanzanian side it is admitted that "it was serious, it is not forgotten the tensions were still there" (Mwinyi 2014: interview) but that shared interests and border will compel improvement. That did not occur, however, before Kikwete ordered the Tanzania People's Defence Forces (TPDF) to expel 20000 Rwandans he claimed were living illegally in Tanzania, showing direct human security implications resulting from perceived differences in national security interests and personal animosity between leaders (The East African, 10/08/13).

\section{Conclusion - continued hope}

This paper has shown that fault lines between post-colonial nation building projects in East Africa and the efforts at regional integration 
facilitated the collapse of EAC I, and in some ways have been replicated with the creation of EAC II. The lack of a genuine sense of citizenship by groups comprising the nation-states has led to many of the insecurities faced by diverse and specific ethnic and cultural groupings, which so far are not likely to be superseded by a sense of belongingness to the emergent EAC II. Within EAC II, the continued prominence of the Summit and President's personalities at the expense of a genuine people-centred approach helps differences of national interest become manifest, helping prevent human security consciousness amongst militaries to evolve.

It has also hinted at opportunities for a more people-centred institution to evolve. Whilst the current personalities of Presidents continue to dominate EAC II, there is enough of an institutional framework to encourage regional cooperation amongst civil society organisations and community groups to tap in to, manipulate, and apply pressure to, in order for leaders to bend to the integration will of their people and citizens. There is change in the treaty from EAC I so that the public could view Council of Ministers as the most prominent organ if it were to assert itself more forcefully (Deya 2007: 130). The (future) citizens of East Africa retain hope and belief that a united federation will occur, perhaps even more so than their respective leaders. And numerous EALA representatives remain committed to holding partner state governments accountable over issues such as use of natural resources, or in adopting a regional framework for negotiating conflict resolution. EAC officials also retain a healthy weariness around military build-up in certain states.

Whilst the EAC II at present retains its elitist and nationalistic origins, resulting in the divide outlined above between its leaders, between the people and the EAC institution, and between the people and their security environment; it nonetheless provides a forum and potential target for domestic groups with regional cooperative agendas to pressure leaders on all sides to include them in the decision making agenda of national and regional nation-building endeavours. It must be, therefore, the task of East African peoples to wrestle control of the EAC II institution from the leaders currently risking its survival. In order for that regional institution to ultimately triumph, however, and a successful political entity of East Africa to provide a secure, inclusive environment for its citizens, it is essential that such domestic pressure consistently include the regional agenda in its methodology and aspirations. 


\section{Endnotes}

1. In April 1964 Tanganyika merged with the Zanzibar Archipelago, to become Tanzania.

2. Details of these discussions and events can be found from "Report of the Meeting of the Sub-Committee on Defence and Security 21st August 1996"; "4th Meeting of the Permanent Tripartite Commission for the East African Cooperation, 12th March".

3. The EAC Common Market began operating in 2005; the Customs Union in 2010; the EAC East African Monetary Union Protocol was signed in 2014, aiming to establish a common currency by 2024.

4. "Report of the EAC Inter-Parliamentarians Relations Liaison Committee on Natural Resources on the site tour of Tanzanian Extractive Industries, Shinyanga - Kahama - Mwanza", 19-23 November 2008; "Report of the EAC Inter-Parliamentary Relations Liaison Committee on Natural Resources on the site tour of Tullow Oil Industries in Hoima District, Uganda", 14-19 June 2009.

\section{Bibliography}

Akech, J A. (2007), "The East African Community: Miracle or Mirage?", in East African Scenarios Project Research Compendium. Nairobi: Society for International Development, pp 81-106.

Akech, M (2009), Privatization and Democracy in East Africa: The Promise of Administrative Law. Kampala: East African Educational Publishers.

Biswaro, J M (2012), The Quest for Regional Integration in Africa, Latin America and Beyond in the Twenty First Century: Experience, Progress and Prospects. Brasilia: Fernando Morais.

Boas, M and K M Jennings (2008), "War in the Great Lakes Region and Ugandan Conflict Zones: Micro-regionalisms and Meta-narratives", in Soderbaum, F and I Taylor (eds), Afro-regions: The Dynamic of Cross-border Microregionalsim in Africa. Stockholm: Elanders Sverige, pp 153-170.

Chikwanha, A (2007), "The Anatomy of Conflicts in the East African Community (EAC): Linking Security With Development Theme for 2007 - Development Policy and the Security Agenda for Africa: Reassessing the Relationship", Keynote speech to Development Policy Review Network-African Studies Institute, Leiden University, The Netherlands.

Chikwanha, AB (2012), "Governance, Citizenship, and Conflicts in the East African Community", Africa Peace and Conflict Journal, Vol 5, No 1, pp 14-27.

Coleman, K P (2011), "Innovations in 'African Solutions to African Problems': The Evolving Practice of Regional Peacekeeping in sub-Saharan Africa", The 
Journal of Modern African Studies, Vol 49, pp 517-545.

Constitutive Act of the African Union: adopted in 2000 at the Lome Summit (Togo).

Deya, D (2007), "An Institutional Analysis of the East African Community: Some Initial Reflections" in East African Scenarios Project Research Compendium. Nairobi: Society for International Development, pp 107-144.

EAC, History of the EAC. (Available at: http:/www.eac.int/index.php?option=com content\&view=article\&id=44\&ltemid=54, last accessed 9 April 2015.)

East African Co-operation Development Strategy (1997-2000). Arusha: Secretariat of the Permanent Tripartite Commission for East African Cooperation

El-Affendi, A (2009), "The Perils of Regionalism: Regional Integration as a Source of Instability in the Horn of Africa?", Journal of Intervention and Statebuilding, Vol 3, No 1, pp 1-19.

Gingyera-Pinycwa, A G G (2007), "Governance and Regional Integration In East Africa", in East African Scenarios Project Research Compendium. Nairobi: Society for International Development, pp 145-176.

Goldstein, A (2002), "The New Regionalism in Sub-Saharan Africa: More than Meets the Eye?", OECD Development Centre, Policy Brief No 20.

Goodfellow, T and S Lindemann (2013), "The clash of institutions: traditional authority, conflict and the failure of 'hybridity' in Buganda", Commonwealth and Comparative Politics, Vol 51, No 1, pp 3-26.

Irele, A and B Jeyifo (2010), The Oxford Encyclopedia of African Thought: Independence movements - Yemoja. Oxford: Oxford University Press.

Katumanga, M (2007), "Geostrategic Implications Of Shirikisho La Afrika Mashariki", in East African Scenarios Project Research Compendium. Nairobi: Society for International Development, pp 299-325.

Kayunga, S S (2005), "Deepening Political Integration of the EAC Countries: The Uganda Case", in Mohiddin, Ahmed (ed), Deepening Regional Integration of the East African Community. Addis Ababa: DPMF, pp 149-226.

Kimbugwe, $\mathrm{N}$ et al (2012), Economic Development Through Regional Trade: $A$ Role for the New East African Community? New York: Palgrave Macmillan.

McAuslan, P (2013), Land Law Reform in Eastern Africa: Traditional or transformative? A Critical Review of 50 Years of Land Law Reform in Eastern Africa 1961-2011. New York: Routledge.

Mistry, P (2000), "Africa's Record of Regional Cooperation and Integration", African Affairs, Vol 99, No 397, pp 553-573.

Mohiddin, A (2005), "Introduction: Deepening Political integration in the East African Community", in Mohiddin, A (ed), Deepening Regional Integration of the East African Community. Addis Ababa: DPMF, pp 1-20.

Nabudere, Dani W. (2006), "The Fast-Tracking of Federation and Constitutionalism in East Africa", Paper presented at The 10th Annual Sir Udo Udoma Sym- 
posium, Makerere University, Kampala, April 2006.

Ndulu, B J and C Mutalemwa (2002), Tanzania at the Turn of the Century: Background Papers and Statistics. Washington DC: World Bank.

Nyabuga, G (2011), "Enhancing Equity in the East African Regional Integration Process: Role of the Media", in Society for International Development (2011) East African Integration Dynamics of Equity in Trade, Education, Media and Labour. Nairobi: SID, pp. 129-172.

OAU (1980), Lagos Plan of Action for the Economic Development of Africa, 19802000, April.

Oloo, A (2007), "East Africa: One Identity or Multiple Identities?", in East African Scenarios Project Research Compendium. Nairobi: Society for International Development, pp. 13-48.

Oluoch, L W (2009), "Legitimacy of the East African Community", Journal of African Law, Vol 53, No 2, pp 194-221.

Soderbaum, F and I Taylor (2008), "Considering Micro-regionalism in Africa in the Twenty-first Century", in Soderbaum, F and I Taylor (eds), Afro-regions: The Dynamic of Cross-border Micro-regionalsim in Africa. Stockholm: Elanders Sverige, pp 13-34.

UN OCHA (2014), Eastern Africa: Displaced Populations Report. Issue 16, 30 September 2013 - 31 March 2014).

UN OSAA (2005), Human Security in Africa, December 2005.

UNDP (1994), Human Development Report, New York: Oxford University Press.

United Nations (2009), Economic Development in Africa Report: Strengthening Regional Economic Integration for Africa's Development. New York and Geneva.

\section{Named Interviewees}

Abdullah Mwinyi, Tanzania, member of the East African Legislative Assembly, (new) Chair of the Regional Affairs and Conflict Resolution Committee, interview with author, January 2015

Abubakar Zein Abubakar, Kenyan, member of the East African Legislative Assembly, former Chair of the Regional Affairs and Conflict Resolution Committee, interview with author, January 2015

Andrew Mwenda, Editor Independent, Uganda, Interview with author, September 2014

David Ndii, Economist, SGR critique, interview with author, February 2015

Flavia Kabahandra, Ugandan Parliamentary Chair for Trade, Interview with author, August 2014

Martin Brownbridge, Economic Advisor to the Governor of Bank of Uganda, 
Interview with author, July 2014

Shem Bageine, Ugandan Minister for EAC, Interview with author, July 2014

Wafula Oguttu, Ugandan MP, Leader of Opposition, Interview with author, August 2014 